\section{Politics of Solitude}

Johan Hartle

Krisis 41 (2): 65-66.

DOI

10.21827/krisis. 41.2 .38244

\section{Licence}

This work is licensed under a Creative Commons Attribution 4.0 License International License (CC BY 4.0). (C) 2021 The author(s). 


\section{Politics of Solitude \\ Johan Hartle}

"For intellectuals, unswerving isolation [Einsamkeit] is the only form in which they can vouchsafe a measure of solidarity. All of the playing along, all of the humanity of interaction and participation is the mere mask of the tacit acceptance of inhumanity" ( $(5)$. This is one of Adorno's descriptions of damaged life in the fifth aphorism of his Minima Moralia. After having missed the historical moment for redemption and reconciliation, the intellectual is, somewhat narcissistically, presented as the one who preserves the universal idea of humanity, which finds itself betrayed by the logic of the everyday, by the false concreteness of popular culture, and the fictitious reality of ordinary people. The postulation is, however, not free of bad conscience. In the next aphorism, entitled "Antithesis", he suggests the exact opposite: by not participating, the intellectual also demonstrates snobbishness, falsely assuming to be better than 'regular' folks.

The general attitude of distance and the loss of social embeddedness reflects the historical experience of exile. Every "intellectual in emigration," Adorno writes, "is, without exception, damaged". Forced to emigrate from Germany under fascism, the experience of deracination and solitude had fully inscribed itself into the intellectual disposition of the first-generation Critical Theorist. This experience of exile following the historical rupture caused by the failure of the progressive working-class movement and the rise of fascism, strengthened and transposed the feeling of loss into an epochal historical perspective.

In this sense, the specific intellectual disposition and the gesture of critique that Adorno suggests bears a strong historical signature. This connects Adorno's thought with various post-colonial perspectives (diaspora philosophy) and even with certain minority politics (if they are critical about dominant milieus and not merely affirming specific identities); but there are also other, less historically contingent, conditions under which the situation of the intellectual is characterized by estrangement, distance, and solitude. Exile and emigration also appear as structural conditions for the position of the intellectual.

For what, really, is an intellectual? In Adorno's concept of the intellectual, the idea of intellectual labor is characterized by various forms of separation, specifically the separation of manual and intellectual labor, and of popular and high culture. In a functionalist understanding of the intellectual (most famously presented by Antonio Gramsci: "All men are intellectuals, but not all men have in society the function of intellectuals."), the intellectual is constituted by her institutional role. In this light (which is not explicitly present, but neither alien to Adorno's account) intellectuals are formed by their position in social institutions (such as universities, museums, concert halls, theatres, public media etc.). In bourgeois societies, such institutions fulfil general, public, and potentially universal tasks. Thus, being constituted and subjectivated by such institutions, also means to represent these ideas, tasks, and societal norms. The intellectual is, as such, a representative of humanism, and of the fiction of bourgeois universalism.

This is where the antinomies of the intellectual, as an embodiment of the norms, begin. Clearly, no one can possibly embody the universal (not the Sartrean universal 
intellectual, for sure). But no intellectual can persist without this fiction. Living by, and according to this fiction, thus means overcoming the gravity of particular interests, of lobby groups, specific cultural milieus, lifestyles, and so forth. It is also in this light that figures of distance, solitude, tactical alienation, and strong affects against "the nice people, the popular ones, who are friends with all" $(\mathbb{S} 3)$ play a decisive role in Adorno's collection of aphorisms.

Ever since the French revolution, so Claude Lefort and others have emphasized, the idea of democracy (equality, universality) was based on the idea that the throne of the king had to remain empty. The intellectual, as a personification of this aporetic idea of universality as an empty seat, has this contradiction inscribed into herself: she cannot be the flesh of universality and thus has to think beyond herself to also leave her own chair empty for an idea of universality that is yet to come, or is at least postponed. This is the existential antinomy by which the intellectual lives, the antinomy that is inscribed into her social role. Distance, estrangement from common life, from popular milieus and mass culture, the solitude of the intellectual, is unavoidable still. She is diasporic and in exile.

Such condition bears, however, as all estrangement, a messianic dream of reconcilement: of the intellectual and the people, of the material organization of social life and the universal claims and promises that bourgeois society have given for the past 250 years. She has to believe in the possibility of real universality and thus has to abstain from "the toasts of cozy sociability".

\section{Biography}

Johan Hartle is the dean of the Academy of Fine Arts Vienna. He held professorships at the State University for Arts and Design Karlsruhe, the Academy of Fine Arts Münster/Westphalia, and the China Academy of Art in Hangzhou. For several years he taught philosophy of Arts and Culture at the University of Amsterdam (UvA). His publications include: Aesthetic Marx (London: Bloomsbury 2017, edited, with Samir Gandesha), The Aging of Adorno's Aesthetics (Milan: Mimesis 2021, edited with Samir Gandesha and Stefano Marino). 